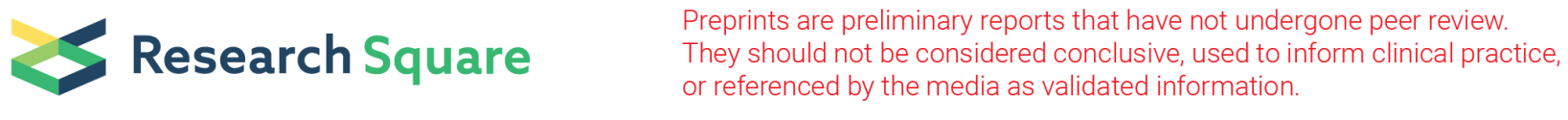

\title{
The Relationship Between Receptor For Advanced Glycation End Products And Obesity: A Systematic Review And Meta-Analysis
}

\author{
Huan DENG \\ Hospital of Chengdu University of Traditional Chinese Medicine \\ Sizhu DENG \\ Hospital of Chengdu University of Traditional Chinese Medicine \\ Qiu CHEN ( $\nabla$ chenqiu1005@cdutcm.edu.cn ) \\ Hospital of Chengdu University of Traditional Chinese Medicine
}

\section{Research Article}

\section{Keywords:}

Posted Date: January 27th, 2022

DOI: https://doi.org/10.21203/rs.3.rs-1165495/v1

License: () (i) This work is licensed under a Creative Commons Attribution 4.0 International License. Read Full License 


\section{Abstract}

With the improvement of nutritional status, the prevalence of obesity is increasing. The occurrence and development of obesity is closely related to the oxidative stress pathway of AGEs production. However, the current research on the correlation between obesity and ages is controversial. Thus, we evaluated the association between obesity and SRAGE. We searched 1,424 articles from PubMed, EMBASE, Web of Science, the Cochrane Library and other resources. Among the 1,424 articles identified, 9 met the inclusion criteria. After the data analysis of research results, it is concluded that the sRAGE of obese patients is lower than normal weight people(MD $[95 \% \mathrm{Cl}]=-247.65[-319.63,-175.67], \mathrm{Z}=6.74, \mathrm{P}<0.00001)$. In conclusion, the results of this meta-analysis revealed a negative correlation between obesity and SRAGE.

\section{Introduction}

Obesity is a global epidemic and has become a serious public health problem. A survey which is published in the lancet, shows that the number of obese adult women worldwide increased from 69 million in 1975 to 390 million in 2016, while the number of obese men increased from 31 million in 1975 to 281 million in $2016^{1}$. Hippocrates wrote "Corpulence is not only a disease itself, but the harbinger of other". Its health risks is well documented, and its prevalence has increased the incidence of cardiovascular disease, type 2 diabetes and many types of cancer worldwide ${ }^{2}$.

Advanced glycation end products (AGEs) are non-enzymatic and oxidative modifications of proteins, lipids or nucleic acids after contact with reducing sugars, also known as Maillard reaction ${ }^{3}$. Serum soluble receptor for advanced glycation end products (RAGE) is a multi-ligand receptor in the immunoglobulin superfamily, which was first isolated from bovine lung in 1992. Many subtypes of rage have been identified, but the most prominent two are the lack of transmembrane and cytoplasmic domains, called truncated or soluble (sRAGE); And endogenous secretion (esRAGE), formed by alternative RNA splicing ${ }^{4}$. Its interaction with AGEs stimulates oxidative stress and stimulates proinflammatory or procoagulant cell responses, including increased expression of vascular cell adhesion molecule-1 and tumor necrosis factor $-a^{5}$. A growing number of clinical trials have demonstrated AGEs-RAGE axis is widely involved in the development of many diseases, including physiological aging and age-related diseases ${ }^{6}$, diabetes ${ }^{7}$, autoimmune/inflammatory rheumatic diseases ${ }^{8}$ (including systemic lupus erythematosus, rheumatoid arthritis, systemic sclerosis), adult-onset Still's disease ${ }^{9}$, kidney disease ${ }^{10}$, and multiple cancers ${ }^{11}$.

The occurrence and development of obesity is closely related to the oxidative stress pathway of AGEs production, as well as the resulting inflammation and endothelial dysfunction ${ }^{12}$. However, the research on obesity and ages RAGE axis is controversial.Some trials showed that RAGE was associated with obesity ${ }^{13}$, while others showed the opposite ${ }^{14}$.Due to the small sample size, these studies cannot provide sufficient evidence to support, Therefore, we conducted this meta-analysis and systematic review to provide more sufficient evidence in this field.

\section{Methods}

\subsection{Protocol:}

We conducted this meta-analysis strictly according to the MOOSE list, and the contents of the system review and meta-analysis have been well reported in the complete MOOSE list (S1 Table).

\subsection{Search strategy:}

Two investigators (HD,SZD) used advanced "glycation end products" OR "AGEs" OR "advanced glycosylation end products" OR "glycosylation end products, advanced" [MeSH] OR "glycation end products receptor" OR "RAGE" AND "obesity"[MeSH] OR "overweight" as the search strategy. Since we retrieve the following database from the database to the data on May 20, 2021: PubMed, EMBASE, Web of Science, the Cochrane Library. Furthermore, references of identified citations and Google Scholar were also searched to identify additional studies. Truncation was used when appropriate to fine-tune the search and increase the number of relevant findings.

\subsection{Selection of articles:}

The retrieval data of different expression formats were imported into Endnote version X9 software (Thomson Reuters, Stamford, CT, USA) for integration, and the same research from different database sources was initially deleted through the "find duplicates" function. The study will be included according to the following criteria: RAGE was detected by blood serum in study; the study should be case-control study; the article was in English in a peer-reviewed journal. The study will be included according to the following criteria: The study designed was animal experiments $\square$ reviews, conference articles and the study was not divided into obesity group and control group. Two authors (DH, SZD) excluded studies obviously unrelated to the purpose of the article by reading the title and abstract, which did not study "obesity" and "RAGE". Then screening eligible study independently selected for full-text review. Divergences were solved by the consensus that was reached in advance. If $>1$ article was published on the same clinical trial, we chose the article with the most complete data. When the research data is incomplete, we try to contact the author of the article to acquire the whole data.

\subsection{Data extraction:}

Two researchers (DH, SZD) independently extracted the relevant data of each study, including: the first author of the study, the year of publication, Country of publication, Publication type, the number of participants, age, body mass index and gender in obesity group and non-obesity group were compared, diagnostic criteria of obesity, matching principle, sRAGE value (Table 1). The form of conversion of RAGE is different in these articles. We convert units to make them consistent by using this formula " $1 \mathrm{ng} / \mathrm{ml}=1000 \mathrm{pg} / \mathrm{ml}$ ". Some of the data are expressed by Inter-quartile range, while others are showed by the sample mean and standard deviation. In order to keep the consistency of data, we used the calculation method of Professor Tong Tiejun to estimate the 
sample mean and standard deviation from the sample size, median, range and/or interquartile range

(http://www.math.hkbu.edu.hk/ tongt/papers/median2mean.html).

\subsection{Literature quality evaluation:}

The Newcastle-Ottawa Scale (NOS) ${ }^{15}$ will be used to evaluate biases in studies included in this meta-analysis. This scale is evaluated from three aspects, including object selection, comparability, outcome, and exposure. By comparing this scale, all studies will be divided into three quality grades based on score: high, and low, and high-quality articles score more than 5 stars, and the lower is 0-5 stars.

\subsection{Data analysis:}

The main outcome of our study is the relationship between serum advanced glycation end product receptor and obesity. According to the characteristics of the subjects, we will conduct subgroup analysis based on age, study area, obesity degree, obesity type, complications, etc.

Rev-man 5.3 software (Cochrane organization, England) will be used for data analysis of the study. In this meta-analysis, we used means and SDs to measure the continuous results of changes in SRAGE. The random effects model will be used for combination analysis of data and reported as mean difference (MD) and $95 \%$ confidence interval. $I^{2}$ statistics is used to evaluate the heterogeneity of meta-analysis, and when it is more than $50 \%$, there may be substantial heterogeneity. "leave one out" is used for sensitivity analysis to evaluate the robustness of the overall results. When more than 10 studies were included in the meta-analysis, publication bias was necessary. Funnel visualization analysis and egger's regression test were used to test publication bias. In all analyses, $\mathrm{P}$ values (two sides) $<0.05$ showed statistical significance.

\section{Results}

\subsection{Characteristics of the eligible studies[}

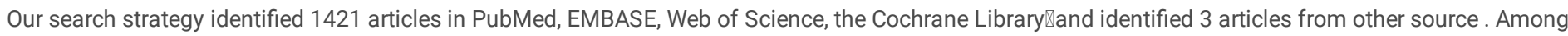
them, there are 479 repeated articles. After analysing the abstract, we excluded 755 essays. After reading the full text, of which 9 articles were included in this meta-analysis. The reasons for exclusion are as follows: The study had no expected results $₫$ The data provided in the article is incomplete囚The article type does not meet the inclusion criteria $₫$ The same research data were applied to multiple articles $₫ T$ he research method is defective. The basic characteristics of the studies included in this meta-analysis are shown in Figure 1. For the definition of obesity, most articles use the diagnostic criteria of BMI, 1 article used the diagnosis of central obesity ${ }^{16}$. The objects of study included adults and children ${ }^{14,17,18}$.

\subsection{Risk of bias assessmentl}

Since this meta-analysis only involved observational studies, we adopted the Newcastle-Ottawa Scale to critically evaluate the quality of the included articles. The scale includes three aspects of evaluation: the selection method of case group and control group, the comparability of case group and control group, and the exposure evaluation method. The more stars after evaluation, the better the quality, preferably 10 stars. If the number of stars is greater than 5 , it will be included in quality research and systematic evaluation and articles with more than six stars are considered of high quality. Fortunately, after an independent evaluation by two researchers, all included studies fulfilled the minimum criteria and retained for systematic review and meta-analysis. A total of six articles were considered high quality and three were considered low quality. (Table 2)

\subsection{Meta-analysis of outcome measures}

The aim of these studies was to explore whether RAGE is associated with obesity. These studies were grouped comparing the value of SRAGE among obese vs normal weight individuals. After the data analysis of research results, it is concluded that the sRAGE of obese patients is lower than normal weight people $\triangle M D[95 \rrbracket C I]=-247.65[-319.63,-175.67] \varangle Z=6.74 \rrbracket P<0.00001 \rrbracket$ (Figure 2$)$. The result from the inconsistency test showed that there was high heterogeneity among the studies analysed (I2=69\%). Thus, the random-effects model was used to calculate the summary measurement.

\subsection{Subgroup analyses}

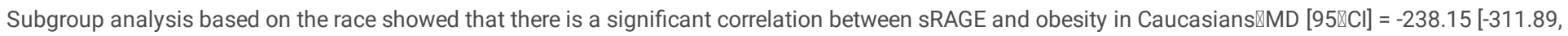

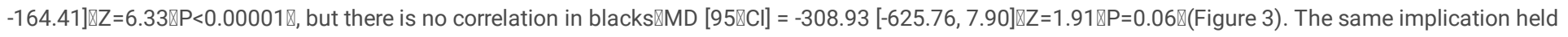
true for the regional subgroups: the European $₫ \mathrm{MD}[95 \nabla \mathrm{Cl}]=-270.12[-322.36,-217.88] \varangle \mathrm{Z}=10.13 \otimes \mathrm{P}<0.00001 \otimes$ and North American $\varangle \mathrm{MD}[95 \otimes C I]=-185.95[-313.38$, $-58.52] \otimes Z=2.86 \otimes P<0.004 \bigotimes$ trials found significant differences in sRAGE between the experimental and control groups, as opposed to the African trials $\varangle \mathrm{MD}$ $[95 \otimes \mathrm{Cl}]=-308.93[-625.76,7.90] \varangle \mathrm{Z}=1.91 \otimes \mathrm{P}=0.06 \otimes$ (Figure 4). At the same time, we evaluated the quality of articles through Newcastle-Ottawa Scale, and conducted a subgroup analysis of the quality of the articles. The results showed that articles in high quality groups had lower heterogeneity $\left(I^{2}=5 \%\right)($ Figure 5$)$

\subsection{Sensitivity analysis}

We removed each trial from the analysis, step by step, in order to discover the impact of each single study on the combine effect size. We observed no significant effect of any individual study on the effect sizes of obesity and sRAGE.

\subsection{Publication bias}

No more than 10 studies were included in this meta-analysis, so there was no study of publication bias. 


\section{Dicussion}

Our study shows that the level of sRAGE in obese patients is lower than that in normal weight people, which is consistent with most previous research conclusions. Obesity, as a hotbed of metabolic diseases, is an important risk factor for the occurrence and development of multiple metabolic diseases. The AGE-RAGE axis, which represents the oxidative stress process, is reflected in many metabolic diseases. It can be regarded as a bridge between obesity and other metabolic diseases, such as diabetes and metabolic syndrome, and our research confirms this assumption.

The formation of ages is a naturally occurring process and the result of normal metabolism. Under the physiological conditions of aging, hyperglycemia, oxidative stress and hyperlipidemia, the formation of ages will increase. So, hyperlipidemialoxidative stress and other features of obese individuals also play a great hole in the production of advanced sugar end products. RAGE is a multi ligand cell surface receptor expressed in three variants. The full-length RAGE and $\mathrm{NH} 2$ truncated variants are retained in the plasma membrane, and the $\mathrm{COOH}$ truncated variant called esRAGE is secreted outside the cell ${ }^{19}$. Enzymatic digestion of full-length cell surface receptors produces another form of full-length RAGE, called sRAGE ${ }^{19,20}$. Due to the lack of cytoplasmic tail and transmembrane domain, it cannot activate intracellular signals. Therefore, it can be used as a competitive receptor of RAGE. It can eliminate the adverse reactions between AGE and RAGE axis by competitive binding with AGE. AGEs can lead to changes in protein function and intracellular glycosylation with impaired cell function. AGEs modifies extracellular matrix proteins, resulting in abnormal interaction between proteins and cells; Circulating AGEs bind to age receptors of different cell types, resulting in the activation of intracellular signaling pathways. These may be the mechanisms by which AGEs can play a role ${ }^{21}$. A large amount of evidence shows that the AGE-RAGE axis leads to the production of pro-inflammatory cytokines, the expression of adhesion molecules and oxidative stress. So far, studies for RAGE with obesity have identified the main downstream effects as high inflammatory response and intracellular oxidative stress $^{22}$. For example, a recent study showed that with the ROS dependent pathway, AGE increased the expression of progesterone / inflammatory regulator and plasminogen activator inhibitor- 1 in rat white adipocytes ${ }^{23}$. In addition, glycosylated BSA increases the fat potential of aging upgrading (in vitro and in vitro) through the Aga RAGE axis and the damage of p53 function ${ }^{24}$. Here, RAGE is directly combined with RAGE inhibition at the p53 transcript level by direct binding of RAGE to cytosolic p53. This in turn enhances the adipogenic potential of ordinary adipocytes and has adverse long-term effects.

Under pathological conditions, AGE gradually accumulates, leading to oxidative stress and vascular inflammation. In our study obesity seems to exacerbate the reduction in SRAGE, suggesting that greater fat causes the deterioration of its metabolic status

SRAGE can be used as a biomarker to predict obesity and other metabolic diseases.Elena et al. Found that sRAGE is closely related to EAT(epicardial visceral adipose tissues), this may indicate that the relationship between SRAGE and obesity is not only reflected in systemic obesity, but also in local obesity. Since EAT is an important risk factor for cardiovascular disease and a consistent correlation with sRAGE has been observed, sRAGE may be considered as an early marker of potential cardiac metabolic risk. in addition, another study further shows that RAGE can modulate atherosclerosis through obesity, and can participate in the progression of atherosclerosis in non-diabetic states ${ }^{25}$. This also requires further research. At present, some studies focus on the possibility of sRAGE signal as a treatment for obesity and its complications, targeting sRAGE and e sRAGE signal transduction, and believe that it is promised as a beneficial drug treatment in the future, or it may be an important strategy for the treatment of obesity and its complications. Our meta-analysis provides further theoretical support.

\section{Conclusion}

In conclusion, the results of this meta-analysis revealed a negative correlation between obesity and sRAGE. However, due to the limited number of articles, further study is needed to provide more support for the relationship between obesity and AGE-RAGE axis. The results may represent a start for more future studies upon the clinical use of sRAGE as an effective medication.

\section{Declarations}

\section{Ethics approval and consent to participate}

Not applicable

\section{Consent for publication}

Not applicable

\section{Availability of data and materials}

All data generated or analysed during this study are included in this published article [and its supplementary information files].

\section{Competing interests}

The Authors declare that there is no conflict of interest.

\section{Funding}

This work was supported by the Subsidy Funds for Improving Medical Services and Guarantee Capabilities (Major Incurable Diseases) [grant numbers: CYW2019079].

\section{Authors' contributions}


Idea conception: HD. Literature retrieval: HD, SZD. Methodology: SZD. Writing-initial manuscript: HD. Review guarantor: QC. All authors participated in the revision of the manuscript and agreed to publish it.

\section{Acknowledgements}

Not applicable

\section{Note}

AGEs $=$ Advanced glycation end products

RAGE $=$ Receptor for advanced glycation end products

SRAGE $=$ Soluble receptor for advanced glycation end products

esRAGE= Endogenous secretion receptor for advanced glycation end products

MOOSE $=$ Meta-analysis of Observational Studies in Epidemiology

NOS $=$ The Newcastle-Ottawa Scale

$\mathrm{SD}=$ Standard deviation

$M D=$ Mean difference

$\mathrm{BMI}=$ Body mass index

ROS=Reactive oxygen species

EAT $=$ Epicardial visceral adipose tissues

\section{References}

1. Worldwide trends in body-mass index, underweight, overweight, and obesity from 1975 to 2016: a pooled analysis of 2416 population-based measurement studies in 128.9 million children, adolescents, and adults. Lancet (London, England). 2017;390(10113):2627-2642.

2. Stefan N, Häring H-U, Hu FB, Schulze MB. Metabolically healthy obesity: epidemiology, mechanisms, and clinical implications. The Lancet Diabetes \& Endocrinology. 2013;1(2):152-162.

3. den Engelsen C, van den Donk M, Gorter KJ, Salome PL, Rutten GE. Advanced glycation end products measured by skin autofluorescence in a population with central obesity. Dermatoendocrinol. 2012;4(1):33-38.

4. Ruiz HH, Ramasamy R, Schmidt AM. Advanced Glycation End Products: Building on the Concept of the "Common Soil" in Metabolic Disease. Endocrinology. 2020;161(1).

5. Zaki M, Kamal S, Kholousi S, et al. Serum soluble receptor of advanced glycation end products and risk of metabolic syndrome in Egyptian obese women. Excli j. 2017;16:973-980.

6. Prasad K. AGE-RAGE stress: a changing landscape in pathology and treatment of Alzheimer's disease. Molecular and cellular biochemistry. 2019;459(12):95-112.

7. Egaña-Gorroño L, López-Díez R, Yepuri G, et al. Receptor for Advanced Glycation End Products (RAGE) and Mechanisms and Therapeutic Opportunities in Diabetes and Cardiovascular Disease: Insights From Human Subjects and Animal Models. Frontiers in cardiovascular medicine. $2020 ; 7: 37$.

8. Hofmann MA, Drury S, Hudson BI, et al. RAGE and arthritis: the G82S polymorphism amplifies the inflammatory response. Genes and immunity. 2002;3(3):123-135.

9. Chen DY, Chen YM, Lin CC, et al. The potential role of advanced glycation end products (AGEs) and soluble receptors for AGEs (sRAGE) in the pathogenesis of adult-onset still's disease. BMC musculoskeletal disorders. 2015;16:111.

10. Sanajou D, Ghorbani Haghjo A, Argani H, Aslani S. AGE-RAGE axis blockade in diabetic nephropathy: Current status and future directions. European journal of pharmacology. 2018;833:158-164.

11. Ahmad S, Khan H, Siddiqui Z, et al. AGEs, RAGEs and s-RAGE; friend or foe for cancer. Seminars in cancer biology. 2018;49:44-55.

12. Corica D, Aversa T, Ruggeri RM, et al. Could AGE/RAGE-Related Oxidative Homeostasis Dysregulation Enhance Susceptibility to Pathogenesis of CardioMetabolic Complications in Childhood Obesity? Front Endocrinol (Lausanne). 2019;10:426.

13. Cinco EDR, Madrigal BR, Rosales JAD, et al. Expression of the receptor of advanced glycation end-products (RAGE) and membranal location in peripheral blood mononuclear cells (PBMC) in obesity and insulin resistance. Iranian Journal of Basic Medical Sciences. 2019;22(6):623-630.

14. Garay-Sevilla ME, Torres-Graciano S, Villegas-Rodriguez ME, Rivera-Cisneros AE, Wrobel K, Uribarri J. Advanced glycation end products and their receptors did not show any association with body mass parameters in metabolically healthy adolescents. Acta Paediatrica. 2018;107(12):2146-2151.

15. Stang A. Critical evaluation of the Newcastle-Ottawa scale for the assessment of the quality of nonrandomized studies in meta-analyses. Eur $\mathrm{J}$ Epidemiol. 2010;25(9):603-605. 
16. Gurecká R, Koborová I, Csongová M, Šebek J, Šebeková K. Correlation among soluble receptors for advanced glycation end-products, soluble vascular adhesion protein-1/semicarbazide-sensitive amine oxidase (sVAP-1) and cardiometabolic risk markers in apparently healthy adolescents: a crosssectional study. Glycoconj J. 2016;33(4):599-606.

17. Davis KE, Prasad C, Vijayagopal P, Juma S, Imrhan V. Serum soluble receptor for advanced glycation end products correlates inversely with measures of adiposity in young adults. Nutrition Research. 2014;34(6):478-485.

18. Chiavaroli V, D'Adamo E, Giannini C, et al. Serum Levels of Receptors for Advanced Glycation End Products in Normal-Weight and Obese Children Born Small and Large for Gestational Age. Diabetes Care. 2012;35(6):1361-1363.

19. Yonekura H, Yamamoto $Y$, Sakurai S, et al. Novel splice variants of the receptor for advanced glycation end-products expressed in human vascular endothelial cells and pericytes, and their putative roles in diabetes-induced vascular injury. The Biochemical journal. 2003;370(Pt 3):1097-1109.

20. D'Adamo E, Giannini C, Chiavaroli V, et al. What is the significance of soluble and endogenous secretory receptor for advanced glycation end products in liver steatosis in obese prepubertal children? Antioxid Redox Signal. 2011;14(6):1167-1172.

21. Gaens KHJ, Stehouwer CDA, Schalkwijk CG. Advanced glycation endproducts and its receptor for advanced glycation endproducts in obesity. Current Opinion in Lipidology. 2013;24(1):4-11.

22. Ramasamy R, Yan SF, Schmidt AM. The diverse ligand repertoire of the receptor for advanced glycation endproducts and pathways to the complications of diabetes. Vascul Pharmacol. 2012;57(5-6):160-167.

23. Uchida Y, Ohba K, Yoshioka T, Irie K, Muraki T, Maru Y. Cellular carbonyl stress enhances the expression of plasminogen activator inhibitor-1 in rat white adipocytes via reactive oxygen species-dependent pathway. The Journal of biological chemistry. 2004;279(6):4075-4083.

24. Chen CY, Abell AM, Moon YS, Kim KH. An advanced glycation end product (AGE)-receptor for AGEs (RAGE) axis restores adipogenic potential of senescent preadipocytes through modulation of p53 protein function. The Journal of biological chemistry. 2012;287(53):44498-44507.

25. Ueno H, Koyama H, Shoji T, et al. Receptor for advanced glycation end-products (RAGE) regulation of adiposity and adiponectin is associated with atherogenesis in apoE-deficient mouse. Atherosclerosis. 2010;211(2):431-436.

\section{Tables}

Table 1: Data extraction table『

\begin{tabular}{|c|c|c|c|c|c|c|c|}
\hline $\begin{array}{l}\text { Year of } \\
\text { publication }\end{array}$ & $\begin{array}{l}\text { Country of } \\
\text { publication }\end{array}$ & $\begin{array}{l}\text { Publication } \\
\text { type }\end{array}$ & participants(experience/control) & age(experience/control) & sexM/F & BMI(experience/control) & results \\
\hline 2016 & Italy & $\begin{array}{l}\text { case- } \\
\text { control } \\
\text { study }\end{array}$ & $37(21 / 16 \rrbracket$ & $34.3 \pm 10.6 / 30.1 \pm 4.9$ & women & $35.4 \pm 3.5 / 22.0 \pm 1.5$ & $640.8 \pm$ \\
\hline 2019 & México & $\begin{array}{l}\text { case- } \\
\text { control } \\
\text { study }\end{array}$ & $40 \rrbracket 20 / 20 \rrbracket$ & $39.5 \pm 1.9 / 37.5 \pm 1.9$ & $17 / 23$ & $33.4 \pm 0.5 / 23.1 \pm 0.3$ & $921.6 \pm$ \\
\hline 2018 & México & $\begin{array}{l}\text { case- } \\
\text { control } \\
\text { study }\end{array}$ & 147凶68/79ه & $\begin{array}{l}16.0(15.0-18.0) / 16.0 \\
(16.0-17.0)\end{array}$ & $40 / 59$ & $28.0 \pm 4.0 / 21.1 \pm 1.9$ & $1605 \pm 4$ \\
\hline 2009 & Slovakia & $\begin{array}{l}\text { case- } \\
\text { control } \\
\text { study }\end{array}$ & $36 \bigotimes 18 / 18 \bigotimes$ & $5-18 / 4-17$ & $19 / 17$ & $27.3 \pm 3.3 / 22.4 \pm 2.1$ & $2300 \pm 1$ \\
\hline 2012 & Italy & $\begin{array}{l}\text { case- } \\
\text { control } \\
\text { study }\end{array}$ & $41(21 / 20)$ & $7.3 \pm 1.2 / 6.4 \pm 1.5$ & $23 / 18$ & $27 \pm 3 / 16.1 \pm 0.4$ & $982 \pm 7:$ \\
\hline 2016 & Slovakia & $\begin{array}{l}\text { case- } \\
\text { control } \\
\text { study }\end{array}$ & 2206(270/1936) & $16.0(17.0-18.0)$ & $1078 / 1128$ & $\begin{array}{l}28.9(26.4-31.2) / 21.4 \\
(19.8-23.4)\end{array}$ & $1410 \pm 4$ \\
\hline 2017 & Egypt & $\begin{array}{l}\text { case- } \\
\text { control } \\
\text { study }\end{array}$ & $200(100 / 100)$ & $31.8 \pm 4.8 / 32.3 \pm 4.3$ & women & $30.24 \pm 5.5 / 25.24 \pm 4.2$ & $955 \pm 5$ \\
\hline 2014 & USA & $\begin{array}{l}\text { case- } \\
\text { control } \\
\text { study }\end{array}$ & $49(5 / 44)$ & $22.8 \pm 4.4 / 23.8 \pm 3.9$ & $22 / 47$ & $34.2 \pm 3.5 / 22.4 \pm 1.8$ & $404 \pm 2$ \\
\hline 2011 & Egypt & $\begin{array}{l}\text { case- } \\
\text { control } \\
\text { study }\end{array}$ & $30(15 / 15)$ & $\begin{array}{l}46.47 \pm 8.03 / 46.67 \pm \\
5.51\end{array}$ & $4 / 25$ & $\begin{array}{l}42.78 \pm 8.33 / 24.45 \pm \\
2.87\end{array}$ & 504.42 \\
\hline
\end{tabular}

Table 2: quality evaluation table囚 


\begin{tabular}{|c|c|c|c|c|c|c|c|c|c|}
\hline Study ID & $\begin{array}{l}\text { 01. Is the } \\
\text { case } \\
\text { definition } \\
\text { adequate? }\end{array}$ & $\begin{array}{l}02 \text {. } \\
\text { Representativeness } \\
\text { of the cases }\end{array}$ & $\begin{array}{l}03 . \\
\text { Selection } \\
\text { of } \\
\text { Controls }\end{array}$ & $\begin{array}{l}04 . \\
\text { Definition } \\
\text { of } \\
\text { Controls }\end{array}$ & $\begin{array}{l}05 . \\
\text { Comparability of } \\
\text { cases and } \\
\text { controls on the } \\
\text { basis }\end{array}$ & $\begin{array}{l}06 . \\
\text { Ascertainment } \\
\text { of exposure }\end{array}$ & $\begin{array}{l}\text { 07. Same } \\
\text { method of } \\
\text { ascertainment } \\
\text { for cases and } \\
\text { controls }\end{array}$ & $\begin{array}{l}\text { 08. Non- } \\
\text { Response } \\
\text { rate }\end{array}$ & total \\
\hline $\begin{array}{l}\text { Valentina } \\
2012\end{array}$ & 口 & & प & प & 吅 & प & प & & 7 \\
\hline $\begin{array}{l}\text { Radana } \\
2016\end{array}$ & 口 & प & ૫ & 口 & प & प & प & & 7 \\
\hline $\begin{array}{l}\text { Moushira } \\
2017\end{array}$ & & & प & 口 & प & प & प & & 5 \\
\hline $\begin{array}{l}\text { Kathleen } \\
2014\end{array}$ & 0 & & प & प & प्र & प & प & & 7 \\
\hline $\begin{array}{l}\text { Mohamed } \\
2011\end{array}$ & प & & ૫ & 口 & प्र & प & प & & 7 \\
\hline $\begin{array}{l}\text { Elena } \\
2016\end{array}$ & $\square$ & & ૫ & 口 & प & & 口 & & 5 \\
\hline $\begin{array}{l}\text { Elizabeth } \\
2019\end{array}$ & प & & प & 口 & प & प्र & प & & 7 \\
\hline $\begin{array}{l}\text { Garay- } \\
\text { Sevilla } \\
2018\end{array}$ & प & & प & प & & प & प & & 5 \\
\hline $\begin{array}{l}\text { KATARINA } \\
2009\end{array}$ & प & प & ૫ & 口 & प & प & प & & 7 \\
\hline
\end{tabular}

\section{Figures}

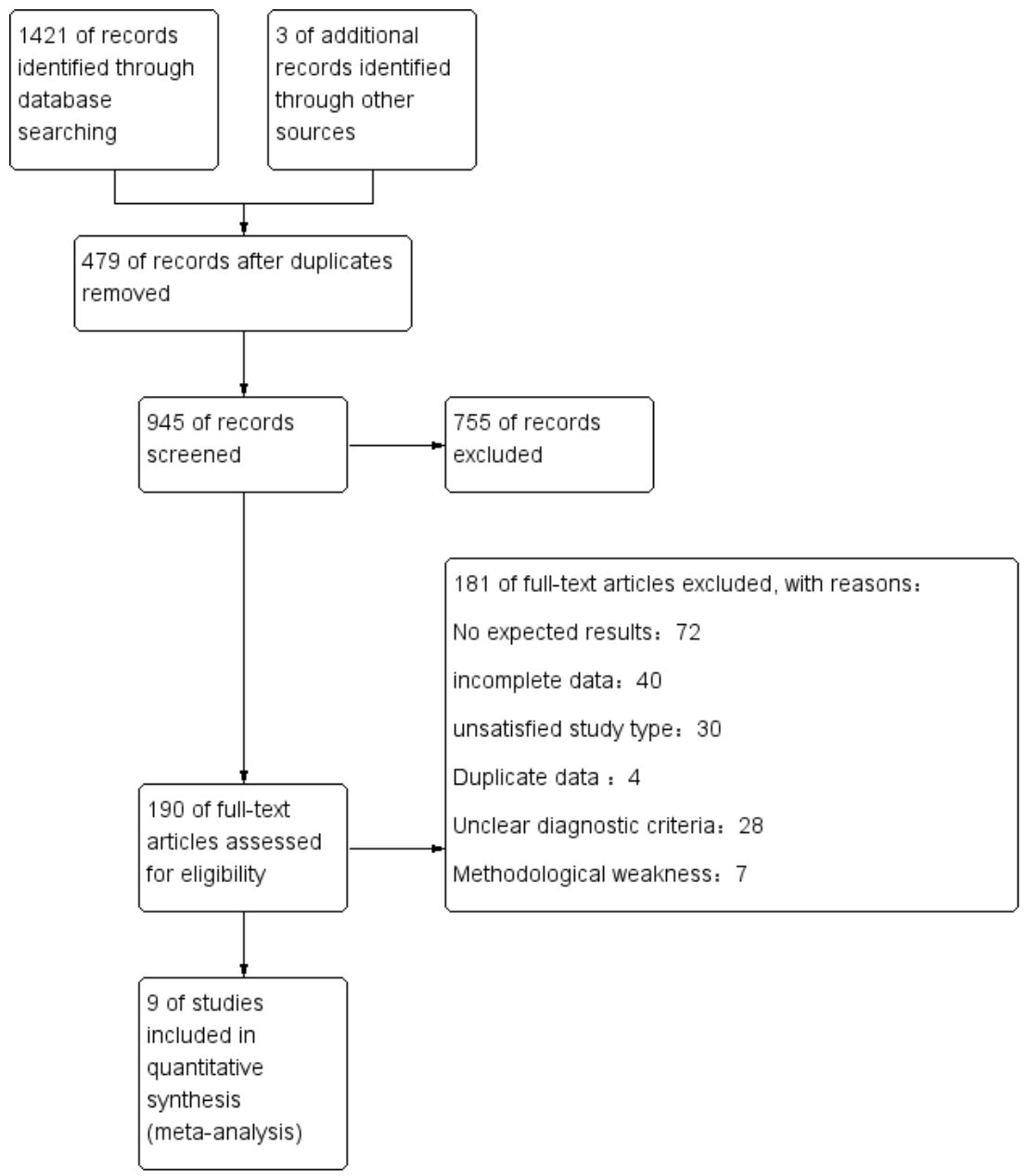

Figure 1

flow diagram. 


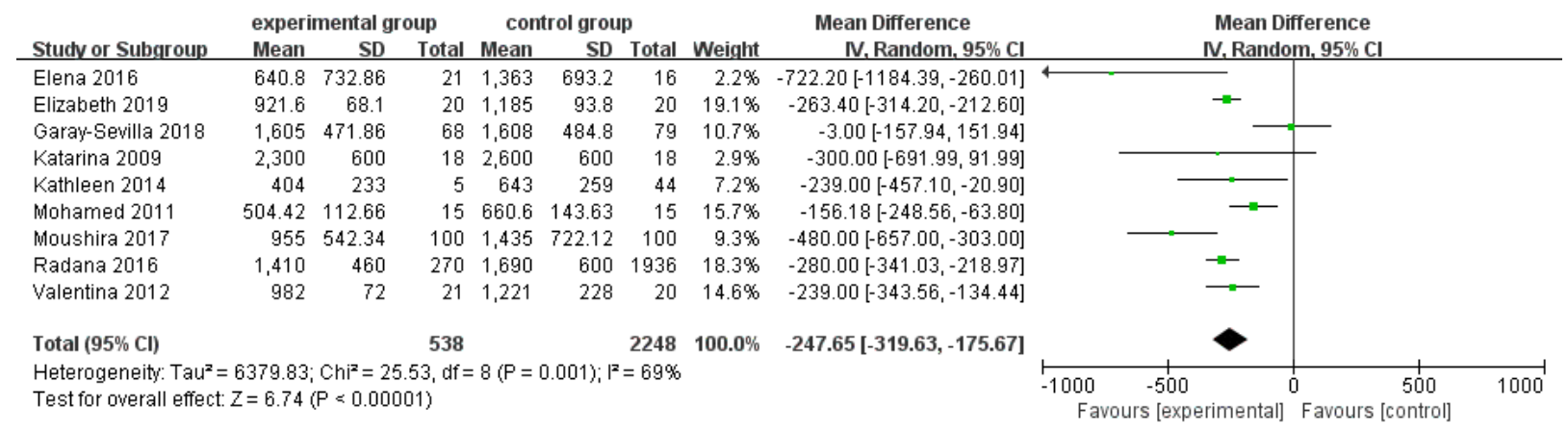

Figure 2

Forest plots for sRAGE and obesity.

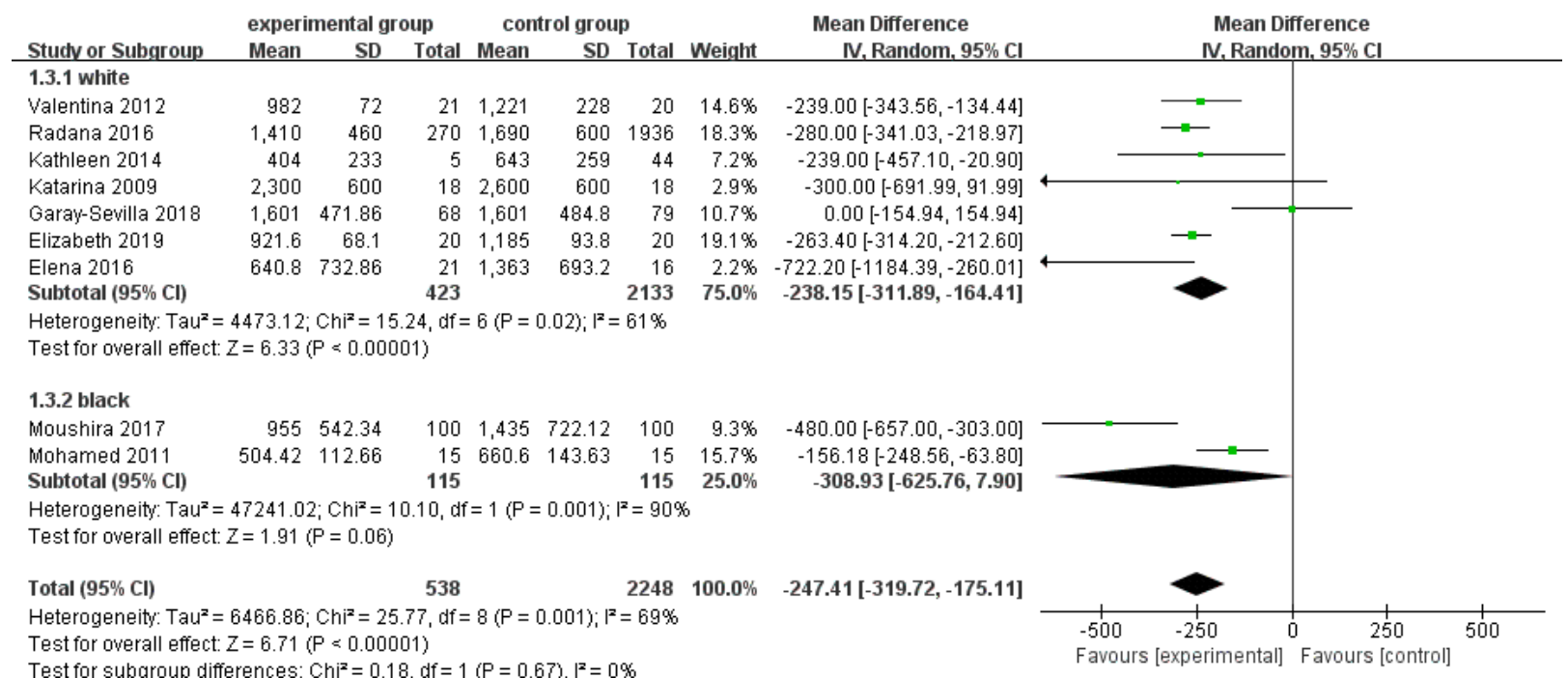

\section{Figure 3}

\section{Ethnic subgroup analysis}

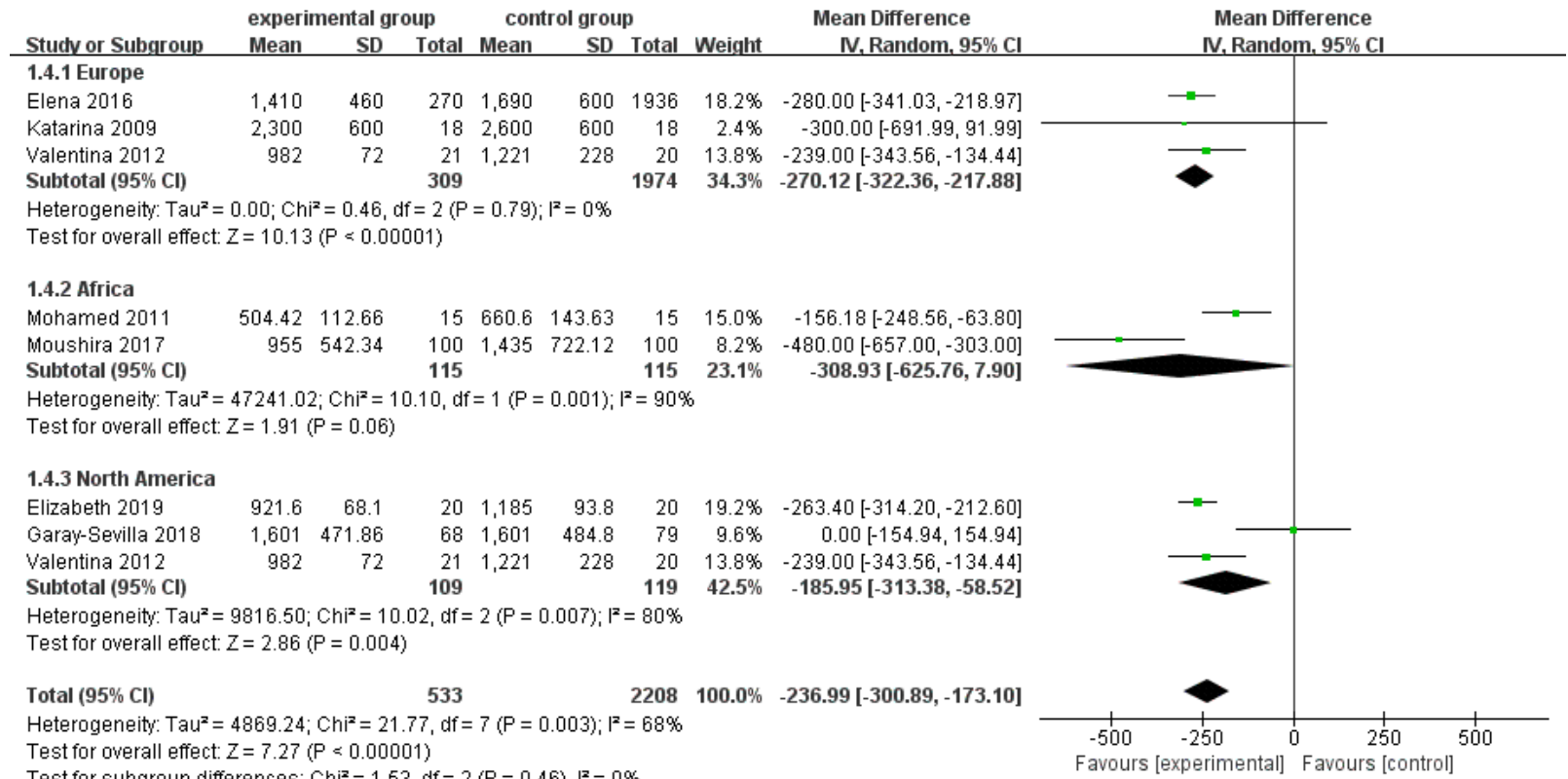

\section{Figure 4}

Regional subgroup analysis 


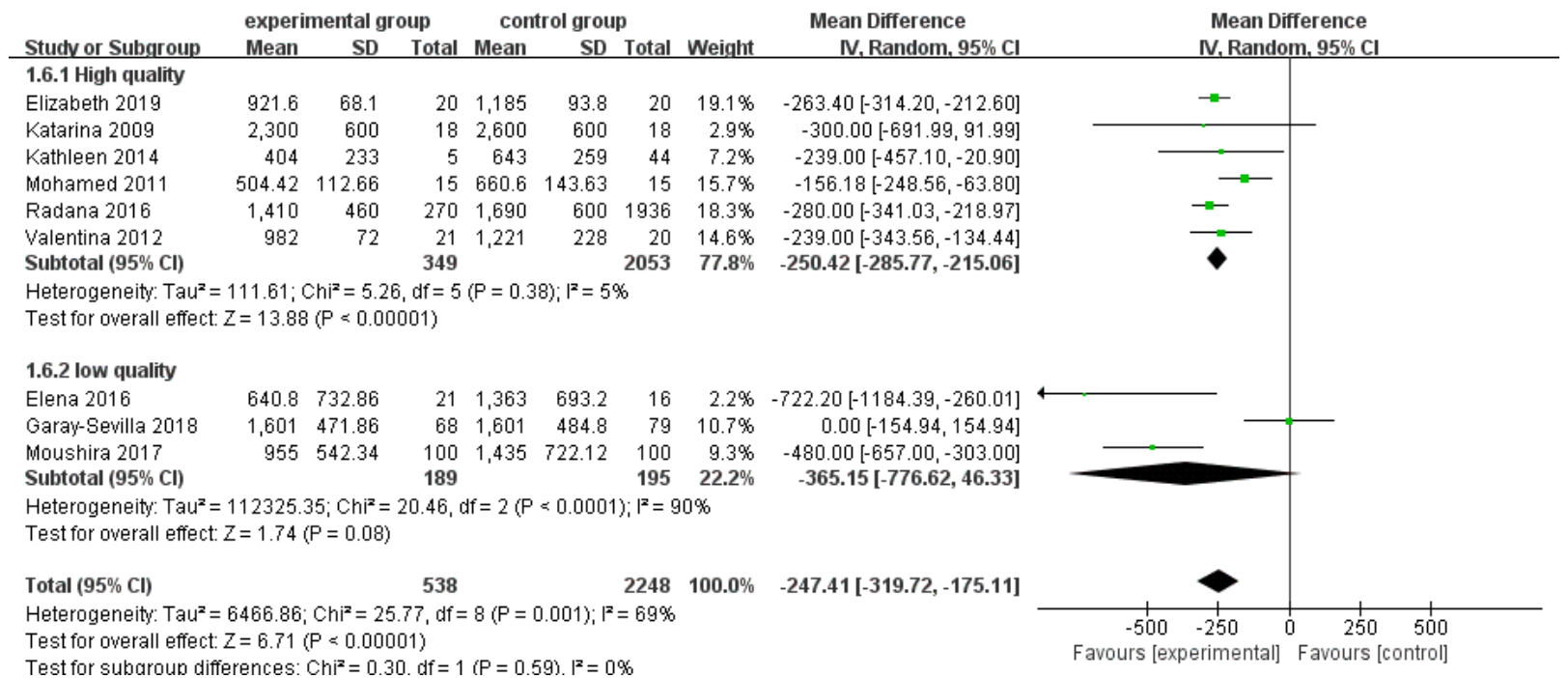

\section{Figure 5}

The article quality was used as subgroup analysis

\section{Supplementary Files}

This is a list of supplementary files associated with this preprint. Click to download.

- S1Table.doc 